УДК 621.574

С.В. Гайдук

Одеська національна академія харчових технологій, вул. Канатна, 112, Одеса, 65039

\title{
МЕТОДИ СТВОРЕННЯ СХЕМИ ТЕПЛОВИКОРИСТАЛЬНОЇ ХОЛОДИЛЬНОЇ МАШИНИ 3 РОБОЧОЮ РЕЧОВИНОЮ ДІОКСИДОМ ВУГЛЕЦЮ
}

В статі розглянутий метод створення схемно-циклового рішення тепловикористальної компресорної холодильної машини з діоксидом вуглечю в якості робочої речовини, базуючись на термодинамічному аналізі «методом ичиклів». Шляхом поетапного нарощування незворотностей, в ииклі-зразку зумовлених дійсними умовами роботи кожного елемента в складі холодильної машини, сформовані еталонні ичикли дійсних машин. На основі аналізу визначений мінімальний елементний склад машини, забезпечуючи реальні прочеси переносу тепла, розширення, стиску, в сукупності з не безпечними умовами роботи машини с діоксидом вуглецю. Приведена оцінка термодинамічної ефективності ичилів для реальних температурних режимів роботи.

Ключові слова: Тепловикористальна холодильна машина - Діоксид вуглеию - Термодинамічний аналіз - Метод ичиклів.

С.В. Гайдук

Одесская национальная академия пищевых технологий, ул. Канатная, 112, Одесса, 65039

\section{МЕТОДЫ СОЗДАНИЯ СХЕМЫ ТЕПЛОИСПОЛЬЗУЮЩЕЙ ХОЛОДИЛЬНОЙ МАШИНЫ С РАБОЧИМ ВЕЩЕСТВОМ ДИОКСИДОМ УГЛЕРОДА}

В статье рассмотрен метод создания схемно-ичклового решения теплоиспользующей ком прессорной холодильной машины с диоксидом углерода в качестве рабочего вещества, базирующейся на термодинамическом анализе «методом ичиклов». Путем поэтапного наращивания необратимостей в ичикле-образие, обусловленными действительными условиями работы каждого элемента в составе холодильной машины, сформированы эталонные ичикль действительных машин. На основании анализа определен минимальный элементный состав машины, обеспечивающий реальные прочессы переноса тепла, расширения, сжатия в совокупности с безопасными условиями работы махины с диоксидом углерода. Дана оиенка термодинамической эффективности ичиклов для реальных температурных режимов работы машиныл.

Ключевые слова: Теплоиспользующая холодильная машина - Диоксид углерода - Термодинамический анализ - Метод ичилов.

\section{S.V. Gayduk}

Odessa National Academy of Food Technologies, 112 Kanatnaja str., 65039

\section{THE CREATION METHODS OF HEAT-USING REFRIGERATION MACHINE WITH CARBON DI- OXIDE AS WORKING SUBSTANCE PATTERN}

The article describes the method of creating a cyclic-scheme decision of heat-using compressor refrigerating machine with carbon dioxide as the working substance, based on the thermodynamic analysis of the "method of cycles». The method of creating of the cyclic-scheme decision of the heat-using compressor machinery with carbon dioxide is based on the thermodynamic analysis of the "method of cycles". Through a phased build-up of irreversible in the cycle - sample (consistent "deterioration» of the ideal cycle) caused by the actual conditions of each element work in the composition of the refrigeration machine, reference cycles of valid machines were formed. Based on analysis, minimum elemental composition was defined, which provided real processes of heat transfer, expansion, compression in total with safe machine operation conditions with carbon dioxide. The estimation of the thermodynamic efficiency of cycles for real temperature machine operation modes was made.

Keywords: Refrigeration machine using heat energy - Carbon dioxide - Thermodynamic analysis Method of cycles.

\section{I. ВСТУП}

Енергетична безпека, економічний розвиток та захист навколишнього середовища погано збалансовані між собою, при цьому економічне зростання тісно зв'язане $з$ попитом додаткової енергії. Невідновні джерела енергії досі грають домінуючу роль в енергетичних ресурсах на планеті, i тенденція економічного розвитку має функцію приросту, тому погіршення екологічної безпеки неминуче.
Покращити ситуацію можна за рахунок використання джерел тепла низького потенціалу, яке масово викидається в атмосферу при проведенні технологічних процесів (виготовлення металу, паперу; продукти горіння палива та ін..).

Використання подібних джерел енергії має сенс для підвищення енергетичної ефективності технологічних процесів та зменшення потреби в використанні первинних ресурсів, оскільки на кожному підприємстві для підтримки технологічного 
процесу і забезпечення тепло-вологістного режиму в приміщеннях потрібен холод, на отримання якого використовують електричну енергію.

Для забезпечення потреби підприємств холодом існують машини, які використовують тепло низького потенціалу (з температурою $100^{\circ} \mathrm{C}$ і вище) і мають назву «тепловикористальні холодильні машини».

До них належать абсорбційні, адсорбційні, ежекторні машини $[1,2]$. Окремий клас тепловикористальних холодильних машин становлять компресорні, у яких реалізується цикл ЧистяковаПлотнікова [3].

У якості робочих речовин в абсорбційних машинах [4] використовують водо аміачний та бромистолітієвий розчини, у ежекторних - речовини НCF-HCFC типу та воду [5].

Компресорні машини переважно проектували 3 R22, R21, RC318 робочими речовинами [3]. Вони мали інтенсивне дослідження і розробку в 60-70 роках минулого століття в ОГАХ на кафедрі холодильних машин у якості транспортних кондиціонерів та систем охолодження надувного повітря до дизельних двигунів внутрішнього згоряння.

В зв'язку з обмеженням на вказані робочі речовини [6] компресорні машини не мають завершеного дослідження.

Відроджуючи дослідження компресорних тепловикористальних холодильних машин, звернемось до діоксиду вуглецю $\left(\mathrm{CO}_{2}\right)$ як робочої речовини.

\section{II. ОСНОВНА ЧАСТИНА}

Машини з $\mathrm{CO}_{2}$ відносяться до старіших типів парових компресорних холодильних машин [7]. В останні роки такі машини інтенсивно розширюють сферу обслуговування: від малих автомобільних кондиціонерів до великих низькотемпературних каскадних комплексів 3 аміаком у верхньому каскаді [8]. Обмеження, зв'язані з великими робочими тисками, сьогодні відсутні завдяки новітнім технологіям у компресоробудуванні та створенні теплообмінних апаратів. Спроби створення тепловикористальної машини досі не було, або ми не володіємо достовірною інформацією відносно цього напрямку у техніці діоксиду вуглецю.

При будь-яких обставинах, розглянемо можливість створення подібних машин.

\section{Вибір термодинамічних зразків для аналізу дійс- ного циклу}

Класичний підхід до створення енергоперетворювальної системи починається 3 термодинамічного аналізу. Він $є$ першою сходинкою в процесі проектування, і за його результатами майбутня система виявляється роботоздатною з високою енергетичною досконалістю або їі подальший розвиток не має практичного сенсу.

Для цього використовують метод циклів, розроблений В. С. Мартиновським [9] і згодом широко застосований при дослідженні парових компресорних машин з чистими робочими речовинами, сумішами речовин, абсорбційних холодильних машин [2].

Основною задачею на початковому етапі проектування будь-якої енергоперетворювальної системи є вибір циклу-зразка. Саме він $є$ основою для створення реальної машини.

Цикли тепловикористальної холодильної машини 3 точки зору термодинаміки - це поєднання прямого і зворотного циклів, в яких використовується єдина робоча речовина, при умові, що зберігається баланс роботи в прямому і зворотному циклах, тому для побудови складного циклузразка потрібні два простих термодинамічні цикли.

Розглянемо цикли-зразки, які використовують для термодинамічного аналізу та граничні умови їх використання. [2]

Цикл Карно - зразок, який використовується для аналізу будь-яких теплоенергетичних установок [10]. Цикл використовують при наявності двох джерел тепла, які не змінюють в процесі теплообміну своїх температур. За таких умов цикл Карно єдиний цикл, який буде відповідати умовам зовнішньої оборотності в ізотермічних процесах теплообміну та внутрішньої оборотності в ізоентропних процесах перенесення теплової енергії від високого температурного рівня до низького (або навпаки). Енергетична ефективність такого циклу залежить тільки від температурної різниці джерел тепла (рисунок 1).

За умови, коли джерела тепла змінюють свою температуру в процесі теплообміну, цикл Карно некоректно використовувати в якості циклу-зразка [10].

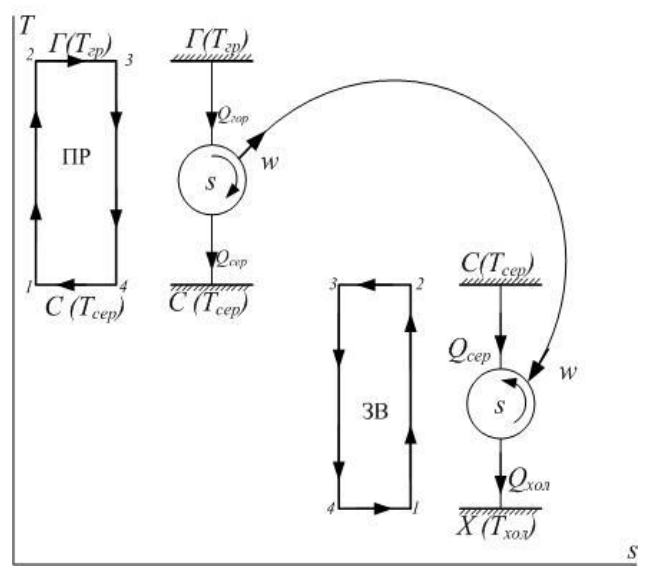

Рисунок 1 - Цикли Карно

ПР - прямий ичикл, ЗВ - зворотній цฺикл

При зміні температури джерела в процесі теплообміну ізотермічні ділянки циклу Карно повинні бути замінені на будь-який зовнішньо оборотні процеси, при яких температура робочої речовини $з$ точністю слідує зміні температури джерел тепла. Враховуючи, що в усіх енергоперетворювальних установках процеси підведення та відведення тепла відбуваються при постійних тисках, в якості циклу-зразка можна вибрати цикл Джоуля (як окремий випадок циклу Лоренца), при постійних ізобарних теплоємностях в процесах теплообміну (рисунок 2) [11]. 
Назва циклу-зразка для тепловикористальних холодильних машин носить здвоєну назву відповідно до складових циклів: перший цикл-прямий, другий-зворотний.

В залежності від поєднання джерел тепла, виникає чотири комбінації циклів: Карно-Карно, Карно-Джоуль, Джоуль-Карно, Джоуль-Джоуль.

Такий вибір комбінації циклів-зразків зроблено в зв'язку з тим, що з $\mathrm{CO}_{2}$ можна реалізувати цикли як в надкритичній, так і в двохфазній областях.

Вибір відповідного циклу-зразка буде пов'язаний з подальшим аналізом дійсних схемних рішень холодильної машини.

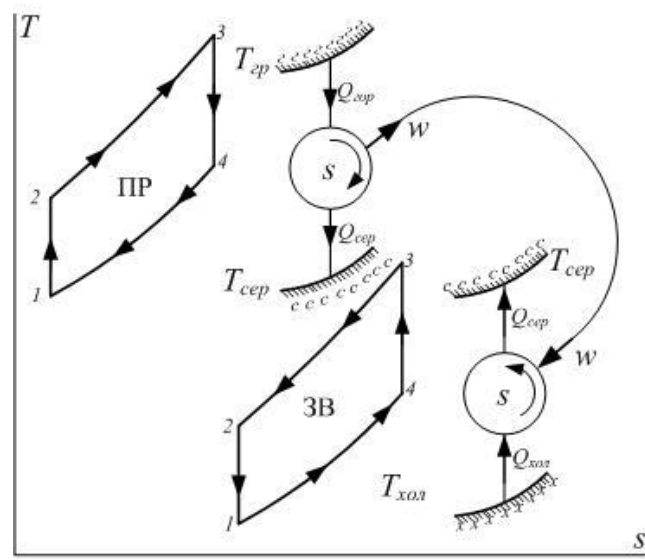

Рисунок 2 - Цикл Джоуля

ПР - прямий цикл, ЗВ - зворотний ичкл

\section{II.I. ЕТАПИ СТВОРЕННЯ СХЕМНО-ЦИКЛО- ВОГО РІШЕННЯ}

Початком термодинамічного аналізу «методом циклів» $\epsilon$ вибір циклу-зразка. На першому етапі аналізу в якості циклу-зразка обираємо прямий і зворотний цикли Карно.

Формування дійсного термодинамічного циклу машини здійснюється за допомогою діаграми стану $T-s$, при використанні конкретних температурних рівнів джерел тепла.

Перший етап - вибір цииклу-зразка та визначення можливих конфігурацій ичиклових рішень.

Цикл 1. Цикл складається 3 двох окремих оборотних циклів Карно (рисунок 3), яких побудовано на граничних температурах: об'єкт охолодження $T_{x о л}=0^{\circ} C$; охолоджуюче середовище $T_{\text {cep }}=30^{\circ} \mathrm{C}$; гріюче джерело $T_{2 p}=125^{\circ} \mathrm{C}$. Цикли побудовано за принципом: витрачена робота в зворотному циклі компенсується отриманою корисною роботою в прямому циклі. Коефіцієнт перетворення $(C O P)$ даного циклу-зразка визначається з рівняння [2]:

$$
\begin{gathered}
C O P_{\text {иикл } 1}=C O P_{n p} \cdot C O P_{\text {зв }}= \\
=\frac{T_{\text {хол }}}{T_{\text {сер }}-T_{\text {хол }}} \cdot \frac{T_{\text {гр }}-T_{\text {сер }}}{T_{\text {гр }}} .
\end{gathered}
$$

Цикл 2. Єдина робоча речовина у прямому і зворотному циклах об'єднує їх в один складний загальний цикл, який має чотири інтерпретації (рисунок 4 - ичикли $2 a, 26,2 в$ і 22).

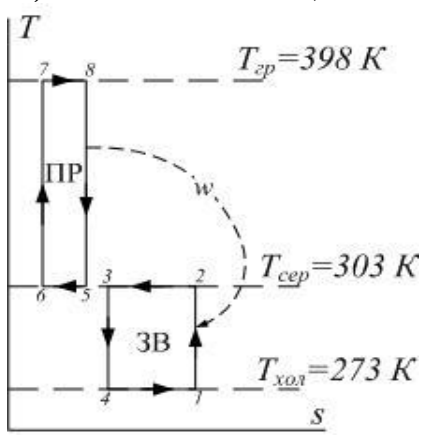

Рисунок 3 - Цикл 1

Всі цикли реалізуються в однаковому діапазоні температур, тому СOP всіх циклів будуть однакові. При детальному розгляді циклів вкажемо на принципові розбіжності в їх формуванні.

В ичиклі $2 a$ можливі два варіанти. Процеси 8-4 та 2-6 єдині для обох циклів, наслідком цього $є$ незмінна масова витрата робочої речовини в складному циклі. Процеси 8-5 та 3-4 розділені і проходять в різних елементах машини, наслідком цього цикли прямий і зворотний працюють самостійно, тоді ідея тепловикористальної машини відпадає.

Цикл 26 - класичний цикл для будь-якої тепловикористальної машини: абсорбційної, ежекторної, компресорної.

Цикл 2в характеризується тим, що стан робочої речовини після розширення в прямому циклі співпадає з станом кінця стиску в зворотному циклі, і процес відведення тепла в навколишнє середовище в них загальний.

Цикл 22 реалізується з єдиним процесом сти-

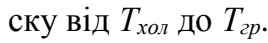

Таким чином площі, які характеризують роботу в прямому і зворотному циклах для циклів $2 a$ і 22 в діаграмі рівні між собою, а для циклів 26 і 26 рівність площ носить логічний вміст, оскільки в прямому і зворотному циклах можуть бути різні витрати робочої речовини.

Другий етап - врахування необоротностей в процесах теплообміну

Цикл 3. Для подальшого аналізу у всіх чотирьох циклах введено зовнішні необоротності в процесах підведення-відведення тепла (рисунок 5.).

Основні робочі температури для робочої речовини будуть такими:

- Температурний напір при відведенні тепла від об'єкта охолодження

$$
\Delta T_{0}=T_{\text {хол }}-T_{0},
$$

де $T_{0}$ - температура робочої речовини;

- Температурний напір при відведенні тепла в охолоджувачі

$$
\Delta T_{\text {cep }}=T_{\text {ox }}-T_{\text {cep }},
$$

де $T_{o x}$ - температура робочої речовини; 


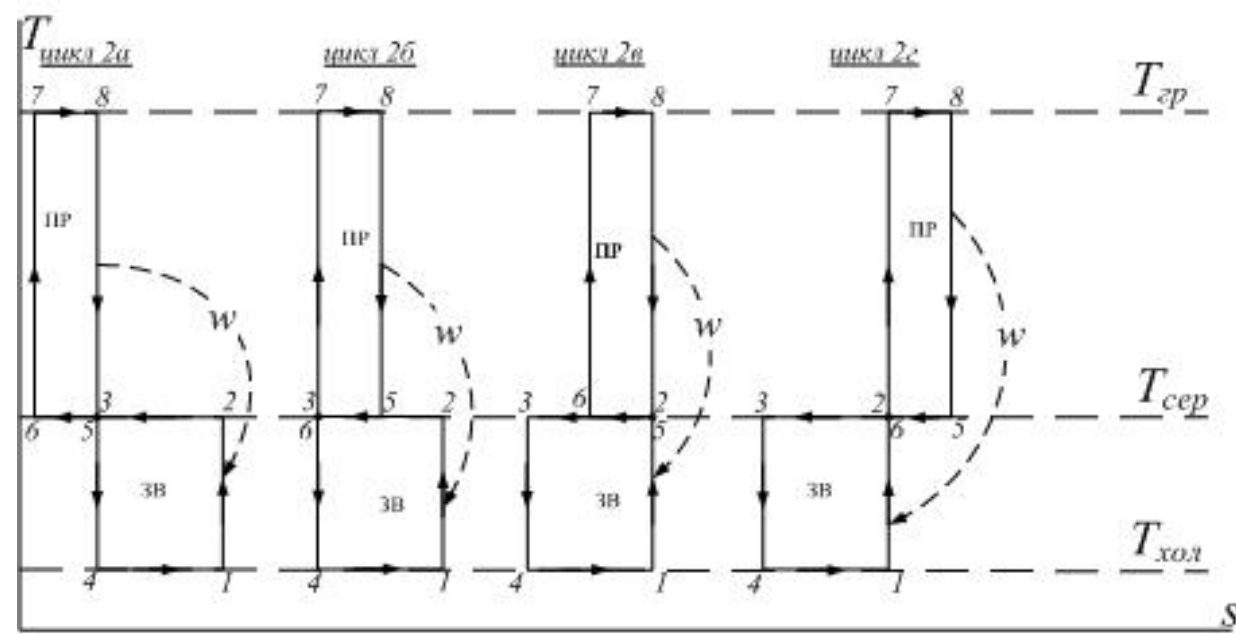

Рисунок 4 - Цикл 2

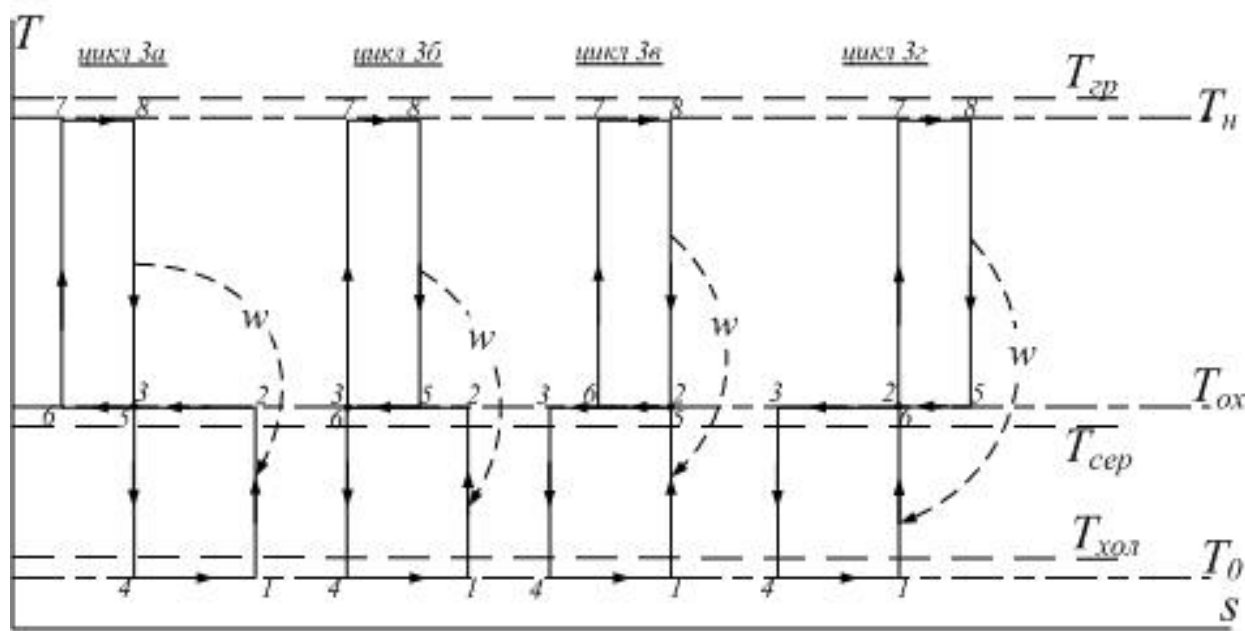

Рисунок 5-Цикл 3

- Температурний напір в нагрівачі

$$
\Delta T_{2 p}=T_{2 p}-T_{H},
$$

де $T_{H}$ - температура робочої речовини.

Аналіз циклів:

- площі зворотного циклу (1-2-3-4) еквівалентні роботі циклу в усіх чотирьох комбінаціях залишаються однаковими;

- введення різниці температур призводить до зменшення кількості відведеного тепла від об'єкта охолодження;

- різниця температур призводить до збільшення роботи в зворотних циклах;

- різниця температур в нагрівачі призводить до зменшення отриманої роботи в прямому циклі. Для виконання умов реалізації складного циклу необхідно в прямих циклах збільшить роботу циклу шляхом збільшення підведеного в нагрівачі тепла.

СОР циклу-зразка визначається рівнянням

$$
\begin{aligned}
& C O P_{\text {чикл } 3}=\frac{\left(T_{\text {хол }}-\Delta T_{0}\right)}{\left(T_{\text {сер }}+\Delta T_{\text {сер }}\right)-\left(T_{\text {хол }}-\Delta T_{0}\right)} \times \\
& \times \frac{\left(T_{2 p}-\Delta T_{z p}\right)-\left(T_{c e p}+\Delta T_{c e p}\right)}{\left(T_{z p}-\Delta T_{2 p}\right)}=
\end{aligned}
$$

$$
=\frac{T_{0}}{T_{o x}-T_{0}} \cdot \frac{T_{H}-T_{o x}}{T_{H}} .
$$

Tpeтій етап - врахування властивостей робочої речовини та визначення еталонного циклу машини.

Цикл 4 - врахування властивостей робочої речовини.

Для відображення властивостей робочої речовини в координати T-s вводять пограничні кривi.

Для подальшого аналізу звертаємо увагу на температурний режим циклу. $\mathrm{CO}_{2}$ має низьку критичну температуру $304 K$, тому завжди температура в нагрівачі буде вища за критичну. В охолоджувачі можливі варіанти: температура джерела вища, рівна або нижча за критичну. Температура об'єкта охолодження завжди нижче критичної.

Використання в якості зразка циклу Карно для аналізу прямого циклу не дає достовірного результату, оскільки практично неможливо виконати процес в нагрівачі зворотним шляхом (в надкритичній області ізобари не співпадають з ізотермами). Джерело має постійну температуру, а робоча речовина - постійний тиск, тому в нагрівачі має місце незворотній процес. Таким чином в яко- 
сті зразка має використовуватися цикл Джоуля, який в реальних умовах реалізується як цикл Брайтона [11]. Пропонується цикл Карно-Карно замінити на Джоуль-Карно (рисунок 6).

На даному етапі аналізу температура в охолоджувачі вища за критичну.

Коефіцієнт перетворення циклу-зразка Джоуль-Карно становит:

$$
\begin{gathered}
\operatorname{COP}_{Д-K}=\frac{T_{0}}{T_{20}-T_{0}} \cdot \frac{T_{2 н}^{m}-T_{20}^{m}}{T_{2 H}^{m}}= \\
=\frac{T_{0}}{T_{20}-T_{0}} \cdot \frac{\int_{s_{7}}^{s_{8}} T d s /\left(s_{8}-s_{7}\right)-\int_{s_{6}}^{s_{5}} T d s /\left(s_{5}-s_{6}\right)}{\int_{s_{7}}^{s_{8}} T d s /\left(s_{8}-s_{7}\right)},(6)
\end{gathered}
$$

де $T_{2 н}^{m}, T_{2 о}^{m}$ - середньопланіметричні температури в газовому нагрівачі і газовому охолоджувачі від- повідно, $K ; S_{7}, S_{8}, S_{6}, S_{5}-$ ентропії робочої речовини у вузлових точках циклу, кДж/(кг К).

Результати аналізу:

- цикли 4б та 4в реалізуються при однаковій температурі в нагрівачі, що пов'язане $з$ різними витратами робочої речовини в циклах;

- цикл 4а потребує збільшення тиску в нагрівачі з одночасним зниженням температури;

- цикл 4г реалізується тільки при значно вищих температурах гріючого джерела.

Цикл 5 - забезпечення надійної роботи компресора зворотного циклу.

Надійна робота компресора забезпечується стиском сухої насиченої або перегрітої пари.

Рисунок 7 демонструє трансформацію зворотного циклу і пов'язане 3 цим збільшення роботи циклу. При збереженні балансу робіт, параметри прямого циклу змінюються відповідно зі зворотним.

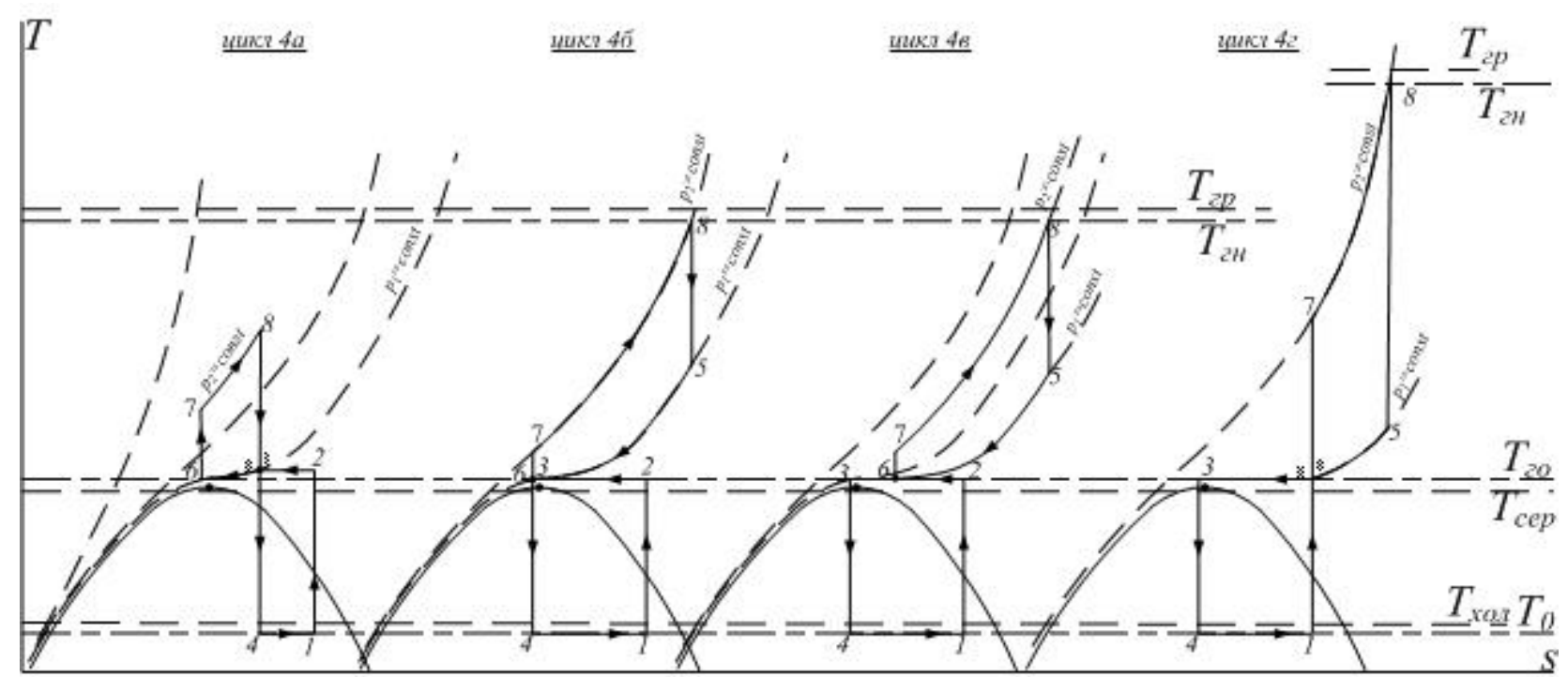

Рисунок 6 - Цикл 4

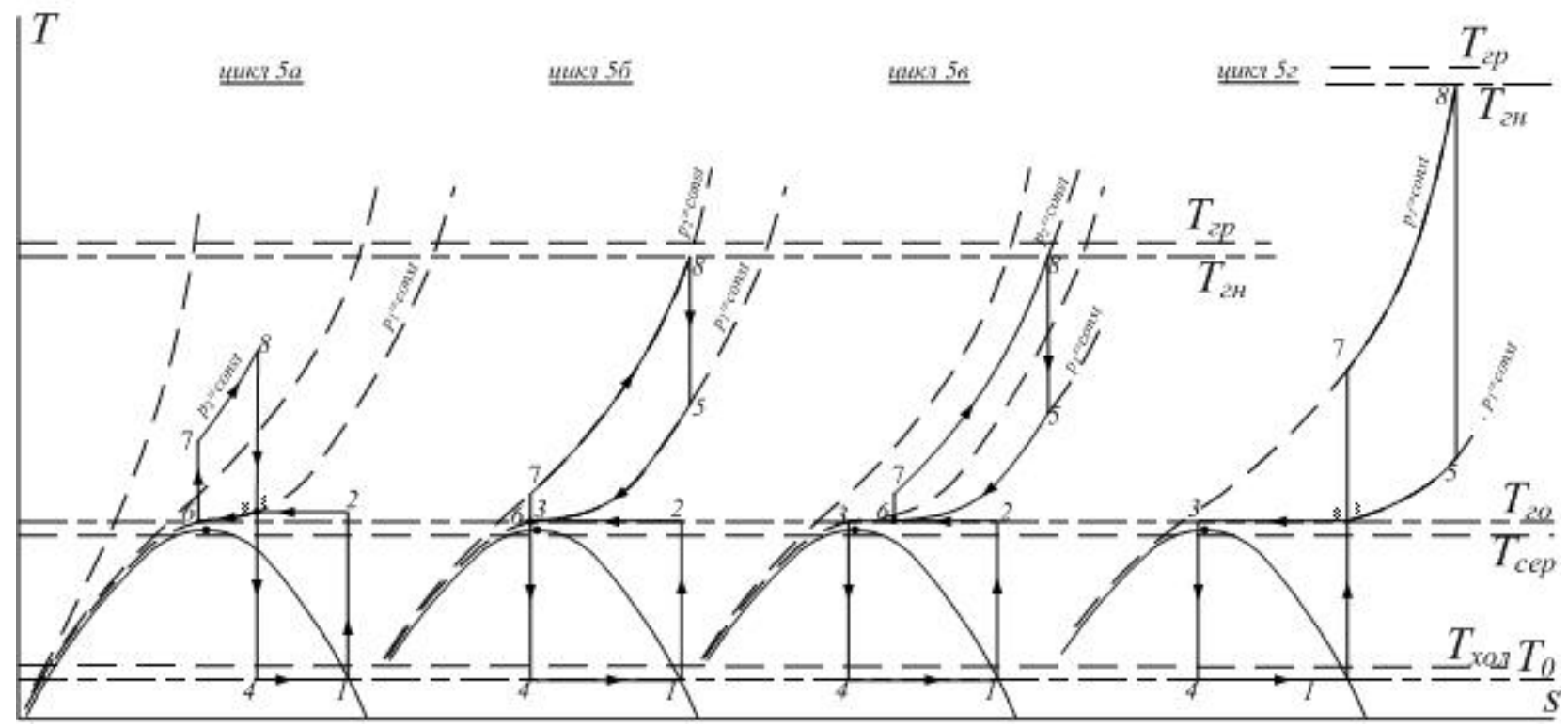

Рисунок 7 - Цикл 5 
Цикл 6 - введення ізобарного процесу теплообміну в газовому охолоджувачі і остаточне формування еталонного циклу.

Процес в газовому охолоджувачі зворотного циклу $є$ ізобарним, з цим пов'язане збільшення роботи зворотного циклу. Процеси в прямому i зворотному циклах мають однаковий тиск, на деяких ділянках однакові температури, що уможливлює використовувати в реальній машині єдиний теплообміний апарат.

Представлені еталонні цикли (рисунок 8.) побудовані за взірцевим циклом Планка для парових компресорних холодильних машин [2]. Цикли мають суттєву відмінність: у зворотному циклі детандер не замінений дроселем. В сучасних машинах $3 \mathrm{CO}_{2}$, на відміну від інших парових компресорних машин, детандер використовується на рівних умовах з дросельним вентилем, тому в еталонному циклі передбачено ізоентропне розширення в області вологої пари [13-14],а врахування необоротності в процесі розширення не $\epsilon$ обов'язковим.

На підставі еталонних циклів розроблено узагальнену схему тепловикористальної холодильної машини 3 діоксидом вуглецю в якості робочої речовини (рисунок 9.).

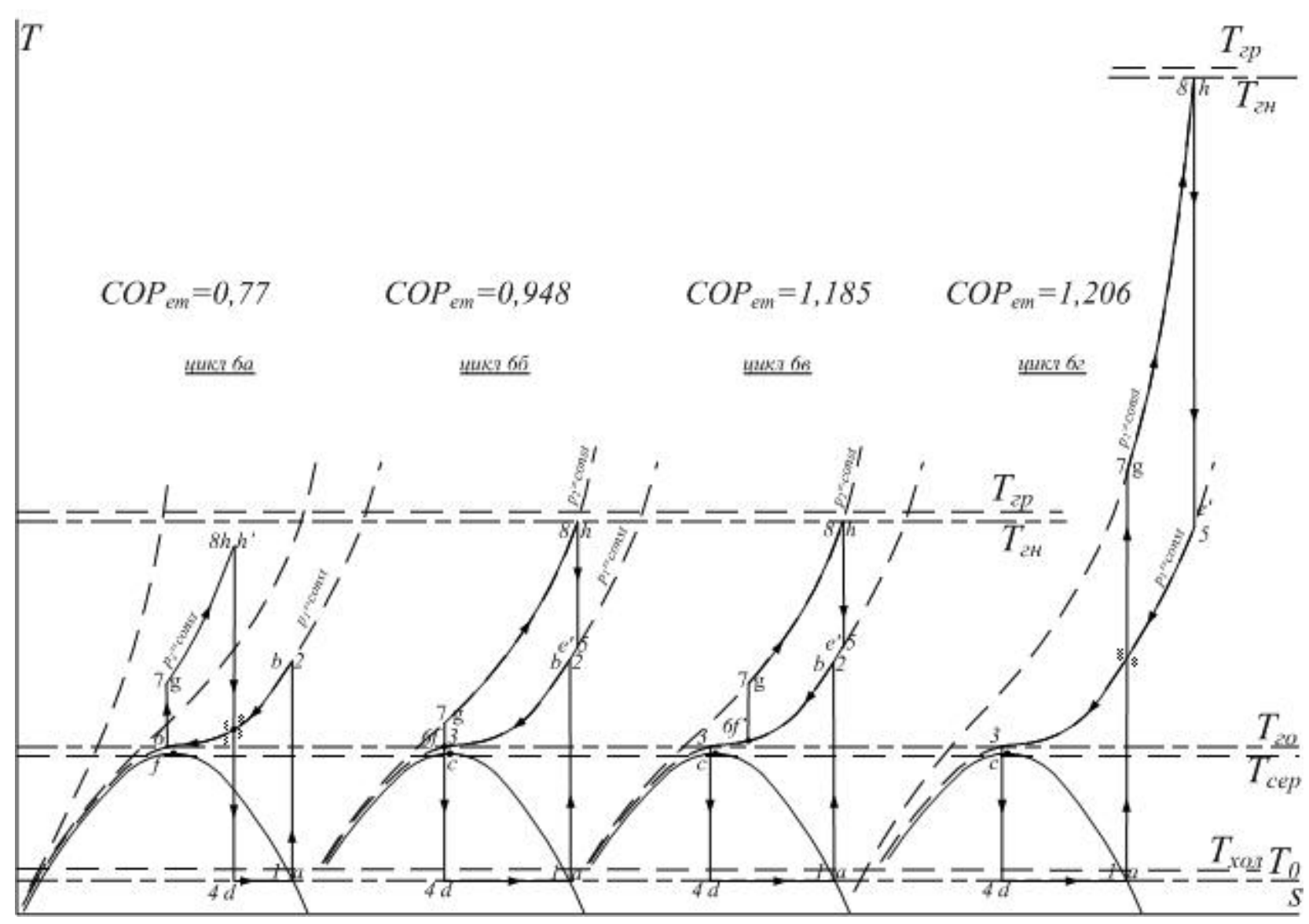

Рисунок 8 - Цикл 6, еталонні цุикли
Назви вузлових точок на циклах співпадають 3 такими на узагальненій схемі.

Коефіцієнт перетворення еталонних циклів визначається рівнянням:

$$
C O P_{\text {em }}=\frac{h_{1}-h_{4}}{f \cdot\left(h_{8}-h_{7}\right)},
$$

де $f$ - відношення витрат робочої речовини в прямому і зворотному циклах; $h_{1}, h_{4}, h_{8}, h_{7}-$ ентальпії робочої речовини в вузлових точках відповідно до циклів, кДж/кг.

Порівняльні розрахунки виконано при однакових умовах для зворотного циклу: $t_{0}=-5^{\circ} \mathrm{C}$, $t_{\text {го }}=35^{\circ} \mathrm{C}$; для прямого циклу - тиск в газовому охолоджувачі 80бар і в газовому нагрівачі 250бар. 3 умови балансів роботи в прямому і зворотному циклах, прямі цикли реалізуються при різних максимальних температурах $\left(t_{8}\right)$ в газовому нагрівачі: циикл $6 a-122,5^{\circ} \mathrm{C}$; ичикл $6 б-120^{\circ} \mathrm{C}$ (єдиний цикл, в якому максимальна температура в газовому нагрівачі не залежить від інших граничних температурних умов); цикл $68-168,9^{\circ} \mathrm{C}$; ичикл $6 z-225^{\circ} \mathrm{C}$. Результати розрахунків коефіцієнтів перетворення еталонних циклів $C O P_{\text {em }}$ вказані на рисунок 9 . Результати циклу 6г співпадають 3 результатами, наведеними в роботі [15]. 


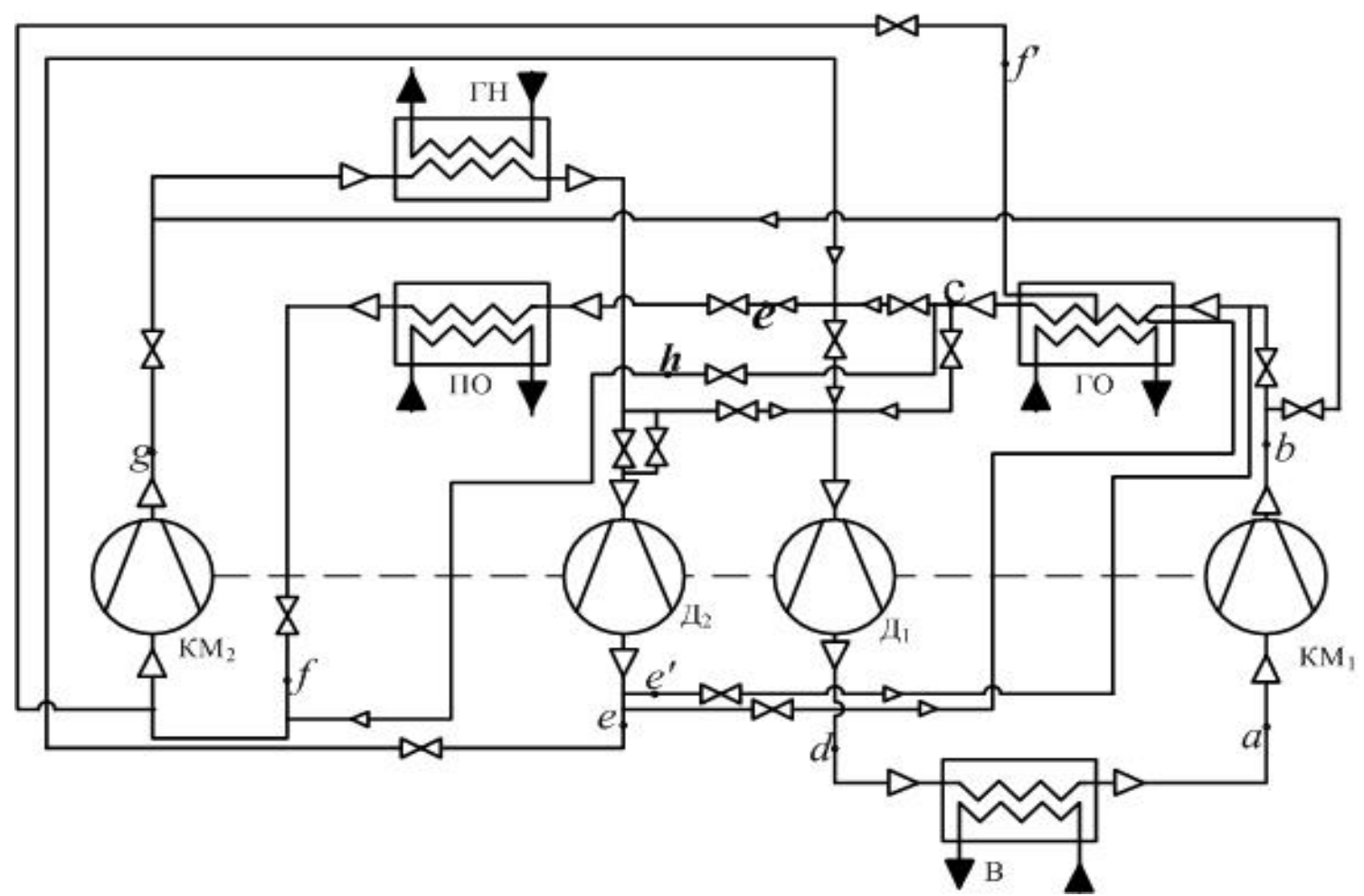

Рисунок 9 - Узагальнена схема тепловикористальної холодильної машини з діоксидом вуглецњю 8 якості робочої речовини.

$\mathrm{KM}_{1}$ - компресор зворотного контуру; ГО - газовий охолоджувач; Д 1 - детандер зворотного контуpy; Д 2 - детандер прямого контуру; КМ 2 - компресор прямого контуру; В - випарник; ПО - проміжний охолоджувач (додатковий); ГН - газовий нагрівач.

\section{ВИСНОВКИ}

Метод циклів може бути використаний для створення схемного рішення будь-якої холодильної машини;

Синтез схемно-циклового рішення з $\mathrm{CO}_{2}$ методом циклів підтверджує положення для тепловикористальних машин - температури двох джерел можуть будуть задані, а третя - $є$ функцією від них [16].

Термодинамічний аналіз, проведений в роботі, довів можливість створення реальних компресорних тепловикористальних холодильних машин, 3 робочими речовинами, які мають низьку критичну температуру.

Наявність узагальненої схеми дозволяє спроектувати тепловикористальну компресорну холодильну машину з діоксидом вуглецю згідно технічного завдання для конкретного споживача.

\section{ЛІТЕРАТУРА}

1. Теплотехніка [Текст]: навч, посібник / Б.Х. Драганов, А.А. Долінський, А.В. Міщенко, С.М. Письменний; за ред. Б.Х.Драганова. - Київ:, «НКОС», 2005. - 504 c.

2. Морозюк, Т. В. Теория холодильных машин и тепловых насосов. [Текст] / Т. В. МорозюкОдесса: Студия «Негоциант», 2006. - 712 с.

3. Чистяков, Ф.М. Холодильные турбоагрегаты [Текст] / Ф.М. Чистяков. - Изд. 2-е перераб. и доп. - М.: Машиностроение, 1974. — 301 с
4. Орехов, И. И. Абсорбционные преобразователи теплоты [Текст]: учеб., пособие / И. И. Орехов, Л. С. Тимофеевский, С. В. Караван. - Л. Химия Ленингр. отд-ние. 1989, 207 с.

5. Шумелишский, М. Г. Эжекторные холодильные машины [Текст] / М. Г. Шумелишский - Государственное издательство торговой литературы москва-1961.

6. Bitzer Kühlmaschinenbau $\mathrm{GmbH}$. Обзор хладагентов. Издание 13. А-501-13. 2004.

7. Padalkar, A. S. Carbon Dioxide as Natural Refrigerant / Padalkar, A. S., Kadam A. D.// International journal of applied engineering research, dindigul .Volume 1,No 2,2010.

8. Горбенко, Г. Л. Применение диоксида углерода в холодильных технологиях[Текст] / Г.Л. Горбенко, И.В. Чайка, П.Г. Гакал, Р.Ю. Турна Технические газы, № 4, 2009 с.18-22.

9. Morosuk, T. Entropy-cycle method for analysis of refrigeration machine and heat pump cycles./ $\mathrm{T}$. Morosuk, R. Nikulshin, L. Morosuk. //THERMAL SCIENCE: Vol. 10 (2006), No. 1, pp. 111-124 c.

10. Мартыновский, В. С. Анализ действительных термодинамических циклов. [Текст] / В. С. Мартыновский - М.: Энергия, 1972. С. 216.

11.Lillo, T. Moore. Development of a Supercritical Carbon Dioxide Brayton Cycle: Improving PBR Efficiency and Testing Material Compatibility/ T. Lillo, W. Windes, T. Totemeier, R. Moore. Idaho National Engineering and Environmental Laboratory (INEEL), October 2004. 
12. Мартыновский, В. С. Циклы, схемы и характеристики термотрансформаторов. [Текст] / В. С. Мартыновский.// Под ред. В. М. Бродянского. М.: Энергия, 1979 - 288 с.

13. Kohsokabe, H. Performance Characteristics of Scroll Expander for $\mathrm{CO}_{2}$ Refrigeration Cycles/ $\mathrm{H}$. Kohsokabe, M. Koyama, K. Tojo, M. Matsunaga,. International Compressor Engineering Conference. Nakayama (2008) Paper 1847.3

14. Matsui, M. Development of High-Efficiency Technology of TwoStage Rotary Expander for $\mathrm{CO}_{2}$ Refrigerant/ M. Matsui, T. Wada Ogata, H. Hasegawa. International Compressor Engineering Conference, 2008.. Paper 1837.

15. Yang, C. Thermodynamic Cycles using Carbon Dioxide as Working Fluid. / C. Yang, School of Industrial Engineering and Management Department of Energy Technology Division of Applied Thermodynamics and Refrigeration. Stockholm, October, 2011.

16. Stierlin, H. Beitrag zum Theorie der Absorptionkaltemaschinen / H. Stierlin, Kaltetechnik.-1964.VoL-16.-P. 213-219.

\section{REFERENCES}

1. Teplotehnika [Tekst]: navch, posIbnik / B.H. Draganov, A.A. Dollnskiy, A.V. MIschenko, E.M. Pismenniy; za red. B.H.Draganova. - KiYiv:, «INKOS», 2005. - $504 \mathrm{~s}$.

2. Morozyuk, T. V. Teoriya holodilnyih mashin i teplovyih nasosov. [Tekst] / T. V. Morozyuk-Odessa: Studiya «Negotsiant», 2006. - $712 \mathrm{~s}$.

3. Chistyakov, F.M. Holodilnyie turboagregatyi [Tekst] / F.M. Chistyakov. — Izd. 2-e pererab. i dop. -M.: Mashinostroenie, 1974. - $301 \mathrm{~s}$.

4. Orehov, I. I. Absorbtsionnyie preobrazovateli teplotyi [Tekst]: ucheb., posobie / I. I. Orehov, L. S. Timofeevskiy, S. V. Karavan. - L. Himiya Leningr. otd-nie. 1989, $207 \mathrm{~s}$.

5. Shumelishskiy, M. G. Ezhektornyie holodilnyie mashinyi [Tekst] / M. G. Shumelishskiy - Gosudarstvennoe izdatelstvo torgovoy literaturyi moskva1961.

6. Bitzer Kühlmaschinenbau GmbH. Обзор хладагентов. Издание 13. А-501-13. 2004.
7. Padalkar, A. S. Carbon Dioxide as Natural Refrigerant / Padalkar, A. S., Kadam A. D.// International journal of applied engineering research, dindigul .Volume 1,No 2,2010.

8. Gorbenko, G. L. Primenenie dioksida ugleroda v holodilnyih tehnologiyah [Tekst] / G.L. Gorbenko, I.V. Chayka, P.G. Gakal, R.Yu. Turna Tehnicheskie gazyi, \# 4, 2009 c.18-22.

9. Morosuk, T. Entropy-cycle method for analysis of refrigeration machine and heat pump cycles./ $\mathrm{T}$. Morosuk, R. Nikulshin, L. Morosuk. //THERMAL SCIENCE: Vol. 10 (2006), No. 1, pp. 111-124 c.

10. Martyinovskiy, B. C. Analiz deystvitelnyih termodinamicheskih tsiklov. [Tekst] / B. C. Martyinovskiy - M.: Energiya, 1972. S. 216.

11. Lillo, T. Moore. Development of a Supercritical Carbon Dioxide Brayton Cycle: Improving PBR Efficiency and Testing Material Compatibility/ T. Lillo, W. Windes, T. Totemeier, R. Moore. Idaho National Engineering and Environmental Laboratory (INEEL), October 2004.

12. Martyinovskiy, V. S. Tsiklyi, shemyi i harakteristiki termotransformatorov. [Tekst] / B. C. Martyinovskiy // Pod red. V. M. Brodyanskogo. - M.: Energiya, $1979-288 \mathrm{~s}$.

13. Kohsokabe, H. Performance Characteristics of Scroll Expander for $\mathrm{CO}_{2}$ Refrigeration Cycles/ $\mathrm{H}$. Kohsokabe, M. Koyama, K. Tojo, M. Matsunaga,. International Compressor Engineering Conference. Nakayama (2008) Paper 1847.3

14. Matsui, M. Development of High-Efficiency Technology of TwoStage Rotary Expander for $\mathrm{CO}_{2}$ Refrigerant/ M. Matsui, T. Wada Ogata, H. Hasegawa. International Compressor Engineering Conference, 2008.. Paper 1837.

15. Yang, C. Thermodynamic Cycles using Carbon Dioxide as Working Fluid. / C. Yang, School of Industrial Engineering and Management Department of Energy Technology Division of Applied Thermodynamics and Refrigeration. Stockholm, October, 2011.

16. Stierlin, H. Beitrag zum Theorie der Absorptionkaltemaschinen / H. Stierlin, Kaltetechnik.-1964.VoL-16.-P. 213-219.

\section{THE CREATION METHODS OF HEAT-USING REFRIGERATION MACHINE WITH CARBON DIOXIDE AS WORKING SUBSTANCE PATTERN}

The article describes the method of creating a cyclic-scheme decision of heat-using compressor refrigerating machine with carbon dioxide as the working substance, based on the thermodynamic analysis of the "method of cycles». The method of creating of the cyclic-scheme decision of the heat-using compressor machinery with carbon dioxide is based on the thermodynamic analysis of the "method of cycles". Through a phased build-up of irreversible in the cycle - sample (consistent "deterioration» of the ideal cycle) caused by the actual conditions of each element work in the composition of the refrigeration machine, reference cycles of valid machines were formed. Based on analysis, minimum elemental composition was defined, which provided real processes of heat transfer, expansion, compression in total with safe machine operation conditions with carbon dioxide. The estimation of the thermodynamic efficiency of cycles for real temperature machine operation modes was made. Keywords: Refrigeration machine using heat energy - Carbon dioxide - Thermodynamic analysis - Method of cycles.

Отримана в редакції 05.02.2014, прийнята до друку 04.03.2014 